\title{
Cluster Analysis of Oxytetracycline and Chloramphenicol Susceptibility in Aeromonas spp. and Escherichia coli from an Aquaculture Environment
}

\author{
Bir Su Ürünleri Yetiştiriciliği Ortamındaki Aeromonas spp. ve Escherichia coli'de \\ Oksitetrasiklin ve Kloramfenikol Duyarllığının Küme Analizi
}

\author{
(D) Avishek BARDHAN, (D) Qurratul Ain QURESHI, (D) Thangapalam Jawahar ABRAHAM
}

West Bengal University of Animal and Fishery Sciences, Faculty of Fishery Sciences, Department of Aquatic Animal Health, West Bengal, India

\section{Abstract}

Introduction: The worldwide growth of aquaculture has led to persistent infections and the emergence of antibiotic-resistant bacteria (ARB). The present study identified the similarity and correlativity of antibiotic susceptibility in the autochthonous bacterial flora of carps cultured in the East Kolkata Wetland and peri-urban Kolkata, India using clustering algorithms based on minimal inhibitory concentration (MIC) data.

Materials and Methods: Motile Aeromonas spp. and Escherichia coli (50 each) isolated in selective media from carps and their environment were tested for susceptibility to oxytetracycline (OTC) and chloramphenicol (CH) using the agar-disc diffusion assay. The MICs of these two antibiotics were determined using the agar dilution method and clustered using the BioNumerics 7.6 software package.

Results: The MICs of OTC and CH varied from 0.39 to $50 \mu \mathrm{g} / \mathrm{ml}$ and 1.56 to $>100 \mu \mathrm{g} / \mathrm{ml}$, respectively. Dendrogram-based cluster analysis of motile aeromonads showed relatively high internal homogeneity, as $>5$ subgroups were obtained under the main clusters. Escherichia coli also showed high internal homogeneity. Dendrogram-based advanced nodal cluster analysis of motile aeromonads as a group yielded a greater number of clusters.

Conclusion: The varied susceptibility among motile aeromonads and $E$. coli isolated from an aquaculture environment with no history of antibiotic use implied the possible contamination of carps with ARB from domestic and hospital effluents. Nevertheless, $E$. coli strains isolated from this environment exhibited high heterogeneity in antibiotic susceptibility, which is a serious cause for concern.

Keywords: Motile aeromonads, Escherichia coli, antibiotics, minimal inhibitory concentration, cluster analysis

\section{Öz}

Giriş: Dünya çapında su ürünleri yetiştiriciliğinin büyümesi, süreğen enfeksiyonlara ve antibiyotiğe dirençli bakterilerin (ARB) ortaya çıkmasına neden olmuştur. Bu çalışma, minimum inhibitör konsantrasyon (MIC) verilerine dayanan kümeleme algoritmalarını kullanarak Hindistan'daki Doğu Kolkata sulak alanında ve Kentsel Kolkata'da kültürlenen sazanların otokton bakteriyel florasındaki antibiyotik duyarlılığının benzerlığini ve bağıntısını tanımlamaktadır.

Gereç ve Yöntem: Sazanlardan ve çevrelerinden seçici ortamda izole edilen hareketli Aeromonas spp. ve Escherichia coli (her biri 50) agar-disk difüzyon deneyi kullanılarak oksitetrasikline ve kloramfenikole duyarlılık açısından test edildi. Bu iki antibiyotiğin MıC'leri, agar seyreltme yöntemi kullanılarak belirlenmiş ve BioNumerics 7.6 yazılım paketi kullanılarak kümelenmiştir.

Cite this article as: Bardhan A, Qureshi QA, Abraham TJ. Cluster Analysis of Oxytetracycline and Chloramphenicol Susceptibility in Aeromonas spp. and Escherichia coli from an Aquaculture Environment. Mediterr J Infect Microb Antimicrob. 2021;10:5. 
Bulgular: Oksitetrasiklin ve kloramfenikolün MıC'leri sırasıyla 0,39-50 ug/ml ve 1,56 ila >100 ug/ml arasında değişmiştir. Hareketli aeromonadların dendrogram tabanlı küme analizi, ana kümeler altında $>5$ alt grup elde edildiğinden, nispeten yüksek iç homojenlik göstermiştir. Escherichia coli ayrıca yüksek iç homojenlik göstermiştir. Bir grup olarak hareketli aeromonadların dendrogram tabanlı gelişmiş düğüm küme analizi, daha fazla sayıda küme vermiştir.

Sonuç: Antibiyotik kullanımı öyküsü olmayan bir kültür balıkçılığı ortamından izole edilen hareketli aeromonadlar ve $E$. coli’de saptanan değiş̧en duyarlılıklar, sazanların ARB'lerle ev ve hastane atıklarından olası kontaminasyonunu düşündürmüştür. Bununla birlikte, bu ortamdan izole edilen $E$. coli suşları, ciddi bir endişe nedeni olan antibiyotik duyarlılığında yüksek heterojenite sergilemiştir.

Anahtar Kelimeler: Hareketli aeromonadlar, Escherichia coli, antibiyotikler, minimum inhibitör konsantrasyon, küme analizi

\section{Introduction}

The use of antibiotics in aquaculture for the prevention or treatment of infectious diseases reduces morbidity and mortality in many species. It encompasses both prophylactic and therapeutic measures but has been accompanied by the rapid emergence of resistant strains, which has become a global issue ${ }^{[1]}$. These resistant strains have been isolated from a wide range of cultured freshwater and marine fish. Aeromonas hydrophila, Mycobacterium marinum, Streptococcus iniae, Vibrio vulnificus and Photobacterium damselae are a few of the resistant strains isolated from various aquaculture species that are also problematic zoonotic pathogens ${ }^{[1]}$. Human and animal infectious diseases can be closely interlinked in a common environment, to which the One Health concept fully applies when addressing the growing issue of antibiotic-resistance ${ }^{[2]}$. Aeromonas is an autochthonous fauna of the aquatic environment, which can be isolated from virtually any water source ${ }^{[3]}$. This genus is a major causative agent of infections in fish, namely motile Aeromonas septicemia ${ }^{[4]}$. Escherichia coli, an indigenous resident of the human gut microbiota, frequently terminates in the aquatic environment mainly due to fecal contamination and demands that numerous international as well as national standards be maintained in fishery products and by-products ${ }^{[5]}$. Escherichia coli plays a crucial role in anthropogenic zoonoses and is classified as a fecal indicator organism ${ }^{[6]}$ and secondary etiological agent in fish pathology ${ }^{[7,8]}$. In India, the major carps, catla (Catla catla), rohu (Labeo rohita), and mrigal (Cirrhinus mrigala) are the mainstays of freshwater aquaculture ${ }^{\left[{ }^{[]}\right.}$. Several earlier studies reported the prevalence of antibiotic-resistant bacterias (ARBs) in cultured fish ${ }^{[10-12]}$, shrimp ${ }^{[13]}$, and fishery products ${ }^{[1,15]}$, but none were found in cluster analysis.

BioNumerics (bioMérieux, France), a software platform that offers countless opportunities for calculating dendrograms, clustering and various statistical analyses, has risen to major prominence over the past few years among various researchers ${ }^{[16,17]}$. This software module can be used to import raw antibiotic susceptibility data (either as minimal inhibitory concentration (MIC) values or inhibition zones); translate it into the categories $\mathrm{S}$ (susceptible), I (intermediate), and R (resistant); and perform diverse cluster analyses. Although this software module has gained vast popularity, its application among the bacterial flora of the aquaculture environment is limited. Clustering is a simple yet convenient way of measuring the intricacies among a target set of data values ${ }^{[18]}$. Clustering analysis aids in targeting and identifying specific groups within a population. Moreover, clustering can be exploited for profit to characterize data from various fields of study, such as science, statistics, economics, social studies, etc. and uncover patterns that can be useful in interpretation ${ }^{[18]}$. Oxytetracycline (OTC) is an approved drug commonly used in aquacultural therapeutics. Chloramphenicol $(\mathrm{CH})$ is an unapproved drug for aquaculture use ${ }^{[19]}$ but frequently ends up in aquatic and aquacultural environments due to its high rate of use by humans. In West Bengal, India, Kolkata metropolitan liquid waste is treated by natural means through a network of canals in peri-urban areas. This massive biological purification system is highly productive, and carp aquaculture is quite popular in the East Kolkata Wetland (EKW) and peri-urban areas ${ }^{[20]}$. The present study assessed the MICs of OTC and $\mathrm{CH}$ against motile aeromonads and E. coli strains isolated from the aquaculture carps of the EKW and peri-urban areas of Kolkata, India between April 2018 and March 2019 and performed dendrogram-based cluster analysis and advanced cluster analysis.

\section{Materials and Methods}

Isolation and Identification of Aeromonas spp. and Escherichia coli

The present study was carried out in two aquaculturally influential districts, viz., North 24 Parganas and South 24 Parganas in West Bengal, India, which contribute to nearly $60 \%$ of the country's aquaculture production ${ }^{[0]}$. Sampling was conducted on three selected fish farms located in peri-urban Kolkata, India, viz., Barrackpore farm (Lat: $22^{\circ} 46^{\prime} 14^{\prime \prime} \mathrm{N}$; Long: 88 $22^{\prime} 41^{\prime \prime} \mathrm{E}$ ), Budherhat farm (Lat: $22^{\circ} 28^{\prime} 50^{\prime \prime} \mathrm{N}$; Long: $88^{\circ} 24^{\prime} 14^{\prime \prime} \mathrm{E}$ ), and Nalban farm (Lat: $22^{\circ} 33^{\prime} 12^{\prime \prime} \mathrm{N}$; Long: $88^{\circ} 24^{\prime} 42^{\prime \prime} \mathrm{E}$ ) and two retail fish markets in Barrackpore (Lat: $22^{\circ} 45^{\prime} 59^{\prime \prime} \mathrm{N}$; Long: $\left.88^{\circ} 22^{\prime} 38^{\prime \prime} \mathrm{E}\right)$ and Garia (Lat: $22^{\circ} 28^{\prime} 57^{\prime \prime} \mathrm{N}$; Long: $88^{\circ} 23^{\prime} 06^{\prime \prime} \mathrm{E}$ ) for 12 months. Both Budherhat and Barrackpore farms were mainly rainwater fed but received domestic and hospital wastewater effluents 
from a nearby locality. The Nalban farm is located in the EKW and is known for sewage-fed aquaculture. These farms had no prior history of antibiotic usage. Healthy cultured Indian major carps (IMCs), viz., L. rohita, C. catla, and C. mrigala of weight 250-350 g were collected during the monthly harvest time and euthanized using clove oil ( $0.25 \mathrm{ml} / \mathrm{l}$ water), wherever necessary. Pond water and pond sediment samples were collected using sterile polypropylene sample containers $(200 \mathrm{ml})$ and plastic borers from the farms with care. The market samples of fresh IMCs, viz., fresh L. rohita, C. catla, and C. mrigala originating from unknown culture systems were also included. Farm and market samples were collected aseptically, placed in an insulated container containing gel ice packs, and transported to the laboratory within two hours of collection. The fish were dissected aseptically, and one part of the edible muscle was homogenized aseptically with nine parts of sterile saline ${ }^{[14]}$. Similarly, the pond water and sediment samples were diluted aseptically in diluent. Loopfuls of homogenized fish muscle, pond water, and pond sediment samples were streaked onto Rimler-Shotts agar supplemented with novobiocin at $10 \mu \mathrm{g} / \mathrm{ml}$ (RSA) and HiCrome E. coli agar (HEA). Bright yellow colonies of presumptive Aeromonas spp. on RSA and luxuriant bluishgreen colonies of E. coli on HEA were picked at random, purified, and identified phenotypically as per standard methods ${ }^{[4,21]}$. The experimental fish were of commercial food value, and the research met the ethical guidelines, including adherence to the legal requirements of India.

\section{Determination of MICs of OTC and $\mathrm{CH}$}

From the pool of approximately 495 bacterial strains isolated from the aquaculture system, 50 strains each of motile Aeromonas spp. [Aeromonas hydrophila $(\mathrm{n}=27), A$. caveae $(n=18), A$. diversa $(n=1)$, and A. tecta $(n=4)]$ and E. coli were used for determination of the MICs of OTC and $\mathrm{CH}$ by the agar dilution method ${ }^{[22]}$. The OTC dihydrate and $\mathrm{CH}$ (HiMedia, India) stock solutions $(1000 \mu \mathrm{g} / \mathrm{ml})$ prepared as per $\mathrm{CLSI}^{[23]}$ were used for the preparation of Mueller Hinton agar (MHA) plates with appropriate antibiotics at concentrations ranging from 0 to $100 \mu \mathrm{g} / \mathrm{ml}$. The MHA plates with OTC and/or $\mathrm{CH}$ at various concentrations were spot inoculated with $2 \mu \mathrm{l}\left(\sim 10^{5}\right.$ cells) of young bacterial culture, incubated for 24 hours at $35 \pm 1^{\circ} \mathrm{C}$ and observed for growth. The lowest concentration of the antibiotic that inhibited visible bacterial growth was considered as the MIC.

\section{Antibiotic Sensitivity Assay}

The sensitivity of motile Aeromonas spp. and E. coli to OTC $(30 \mu \mathrm{g})$ and $\mathrm{CH}(30 \mu \mathrm{g})$ was tested by the agar-disc diffusion technique ${ }^{[22]}$ on MHA at $35 \pm 1^{\circ} \mathrm{C}$ for 24 hours. Interpretation of sensitivity was based on the zone size interpretation chart ${ }^{[22]}$.

\section{Cluster Analysis}

The MIC values of OTC and $\mathrm{CH}$ were fed into the BioNumerics 7.6 software package in the form of an Excel spreadsheet for dendrogram-based cluster analysis and advanced nodal cluster analysis. Clustering was performed by first converting the MIC values of OTC and $\mathrm{CH}$ into categories, i.e., $\mathrm{S}$ for susceptible, I for intermediate, and $\mathrm{R}$ for resistant. The dendrogram was then constructed from the similarity matrix by the unweighted pair group method with arithmetic mean using the BioNumerics version 7.6 software package (bioMérieux, France; http://www. applied-maths.com/bionumerics).

\section{Results and Discussion}

The present study aimed to identify the correlation between MIC values of OTC and $\mathrm{CH}$ against motile aeromonads and $E$. coli from the aquaculture environment in peri-urban Kolkata and to determine their susceptibility pattern. The results for the antibacterial susceptibilities of motile Aeromonas spp. and $E$. colis strains and the MICs of OTC and $\mathrm{CH}$, as presented in Tables 1 and 2, revealed that the MICs of OTC against motile aeromonads and $E$. coli varied between 0.39 and $50 \mu \mathrm{g} / \mathrm{ml}$, and 1.56 and 50 $\mu \mathrm{g} / \mathrm{ml}$, respectively. The MICs of $\mathrm{CH}$ against motile aeromonads and E. coli varied from 3.13 to $>100 \mu \mathrm{g} / \mathrm{ml}$, and 1.56 to $>100$ $\mu \mathrm{g} / \mathrm{ml}$, respectively. Multiple ARB reportedly isolated from cultured fish in India and various countries are emerging as a public health issue ${ }^{[11,14,20]}$. In this study, BioNumerics interpreted the data on the basis of the cluster analysis technique, and the output was obtained as clusters of similar profiles, viz., S, I, or R. These clusters were arranged on the basis of their similarities and dissimilarities, and a hierarchy was obtained. This hierarchy was arranged into a dendrogram as shown in Figures $1 \mathrm{a}, 1 \mathrm{~b}, 1 \mathrm{c}$ for motile aeromonads and Figure 2 for E. coli. The dendrogram for motile aeromonads (Figure 1a) indicates that the MIC values of OTC and $\mathrm{CH}$ against $A$. hydrophila strains formed three clusters $A, B$, and $C$. Figure $1 b$ indicates the clustering of MIC values of OTC and $\mathrm{CH}$ against $A$. caviae strains as clusters $\mathrm{A} 1, \mathrm{~A} 2$, and $\mathrm{A} 3$. The MIC values of OTC and $\mathrm{CH}$ against $A$. tecta strains clustered separately (Figure 1c). For E. coli strains, three clusters were obtained, viz., A, B, and C, which correlated with each other at different similarity levels (Figure 2).

Dendrogram-based cluster analysis provided further insight into the antibiotic susceptibility and patterns of the tested strains from the aquaculture environment, similar to previous works on Campylobacter jejuni ${ }^{[24]}$ and Enterococcus ${ }^{[17]}$. The results obtained from advanced nodal cluster analysis of motile Aeromonas strains mainly depicted the similarity between the different nodes/cluster heads on the basis of differences in the internode distance and connectivity (Figure 3 ). Seven heads were obtained, in which cluster heads I-II, III-IV-V, and VI- 
VII were found to be paired together. All three nodal clusters were interconnected. Node IV clustered the maximum number of strains (27), followed by node III (12). The advanced nodal clustering of $E$. coli strains based on the MIC values depicted a different advanced cluster (Figure 4). A total of eight heads with three different sets of interconnected cluster heads, viz., A-B nodes, C-D-E nodes, and F-G-H nodes were obtained. In node/cluster head $D$, more strains (18) clustered together than in all other cluster heads. Cluster heads $\mathrm{A}, \mathrm{B}$, and $\mathrm{H}$ depicted a singular entity, i.e., strain.

Irrespective of the farm and market samples, the strains clustered together on the basis of their antibiotic susceptibility and did not show location- or source-specificity among clusters. This might imply that samples from farms and markets had been exposed to a similar source of cross-contamination along the production chain, which corroborates the results of Chai et al. ${ }^{[24]}$. Among the $A$. hydrophila strains, the five subgroups were grouped into three clusters, viz., $\mathrm{A}, \mathrm{B}$, and $\mathrm{C}$. Cluster A contained the subgroups of $\mathrm{OTC}^{\mathrm{C}} \mathrm{CH}^{\mathrm{S}}$ strains (a1) and $\mathrm{OTC}^{\mathrm{S}} \mathrm{CH}^{\mathrm{s}}$ strains (a2), both of which shared $50 \%$ similarity. Cluster B contained the single subgroup $\mathrm{OTC}^{\mathrm{S}} \mathrm{CH}^{\prime}$ strain. Cluster $\mathrm{C}$ contained the subgroups of $\mathrm{OTC}^{\mathrm{R}} \mathrm{CH}^{\mathrm{R}}$ strains (c1) and $\mathrm{OTC}^{\mathrm{S}} \mathrm{CH}^{\mathrm{R}}$ strains (c2), each sharing $50 \%$ similarity. Cluster B correlated with both clusters A and $\mathrm{C}$ on the basis of their susceptibility to OTC at similarity levels of $43.30 \%$ and $35.80 \%$, respectively. Correspondingly, cluster

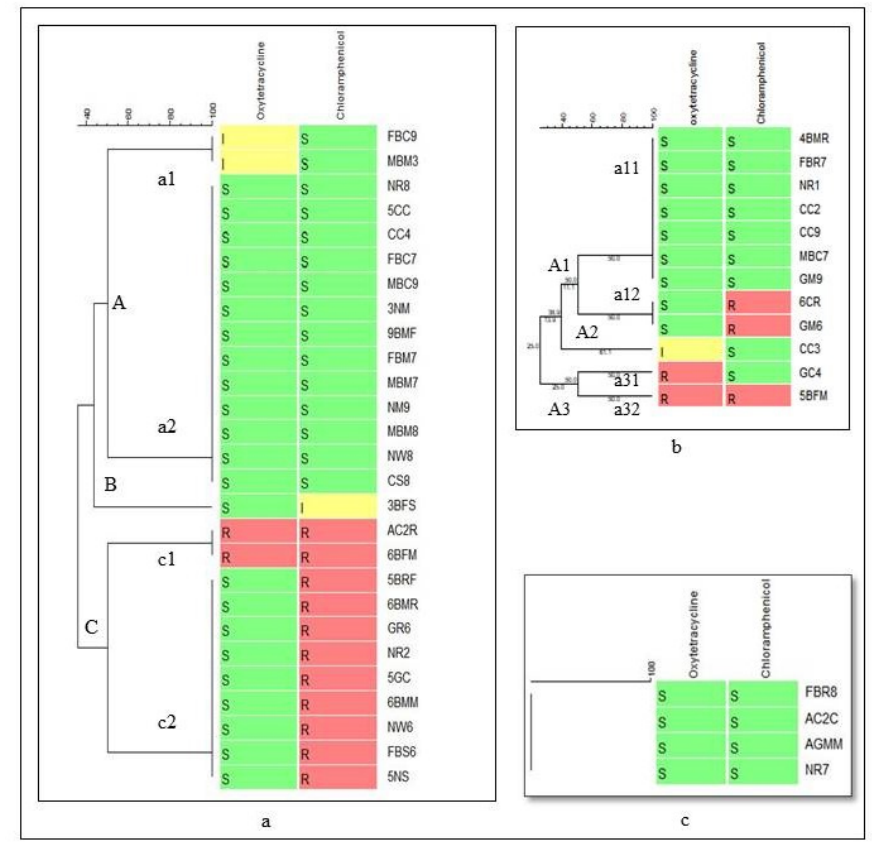

Figure 1. Dendrogram-based cluster analysis of minimal inhibitory concentrations of oxytetracycline (OTC) and chloramphenicol (CH) against selected motile aeromonad strains and their antibioticresistance profiling. The colors in the comparison window correspond to the color of OTC and CH category (susceptible, intermediate, or resistant) as set by BioNumerics
B was formed separately due to its resistance profile of $\mathrm{CH}^{\prime}$, which was unique to all tested strains, maintaining similarity levels below 50\%. Among the A. caviae strains tested for MICs, five subgroups were calculated, viz., the subgroup of $0 \mathrm{OTC}^{\mathrm{S}} \mathrm{CH}^{\mathrm{R}}$ strains (a12); subgroup of $\mathrm{OTC}^{\mathrm{s}} \mathrm{CH}^{\mathrm{s}}$ strains (a11); subgroup of $\mathrm{OTC}^{\mathrm{R}} \mathrm{CH}^{\mathrm{S}}$ strain (a31); subgroup of $\mathrm{OTC}^{\mathrm{C}} \mathrm{CH}^{\mathrm{S}}$ strain and subgroup of $0 \mathrm{OT}^{\mathrm{R}} \mathrm{CH}^{\mathrm{R}}$ strain (a32). Cluster $\mathrm{A} 1$ contained the subgroups a11 and a12. The correlation inside the A1 cluster was solely based on their susceptibility to OTC; whereas the correlation

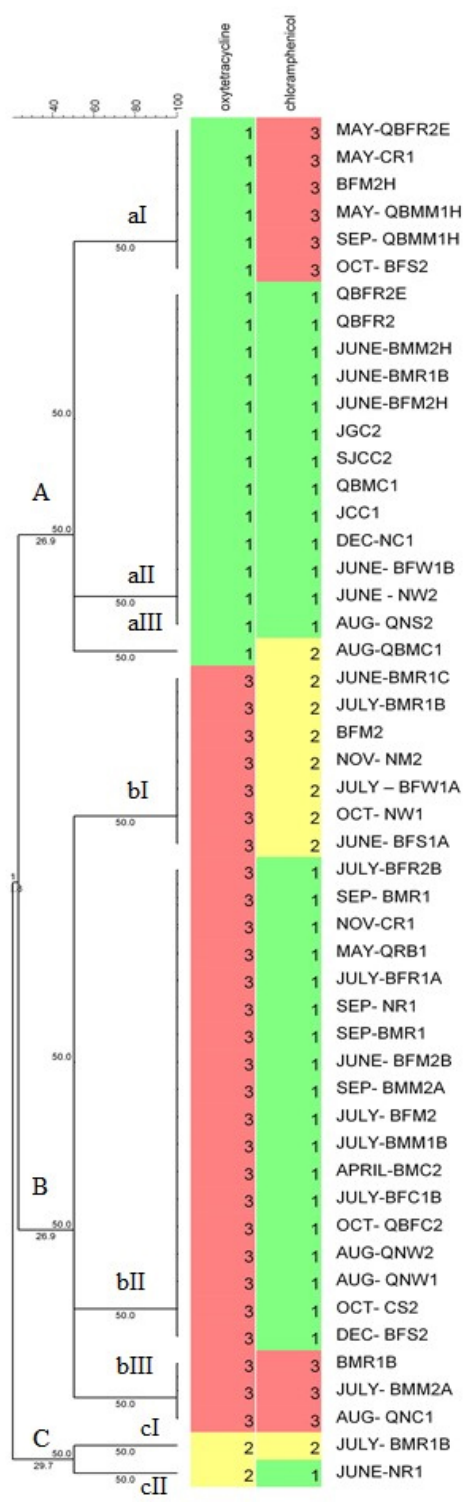

Figure 2. Dendrogram-based cluster analysis of minimal inhibitory concentrations of oxytetracycline (OTC) and chloramphenicol (CH) against selected Escherichia coli strains and their antibioticresistance profiling. The colors in the comparison window correspond to the color of OTC and CH category [susceptible (1), intermediate (2), or resistant (3)] as set by BioNumerics. Under the main clusters viz., $A, B$, and $C$ lie the subgroups al, all, alll, bl, bll, blll, cl, and cll 


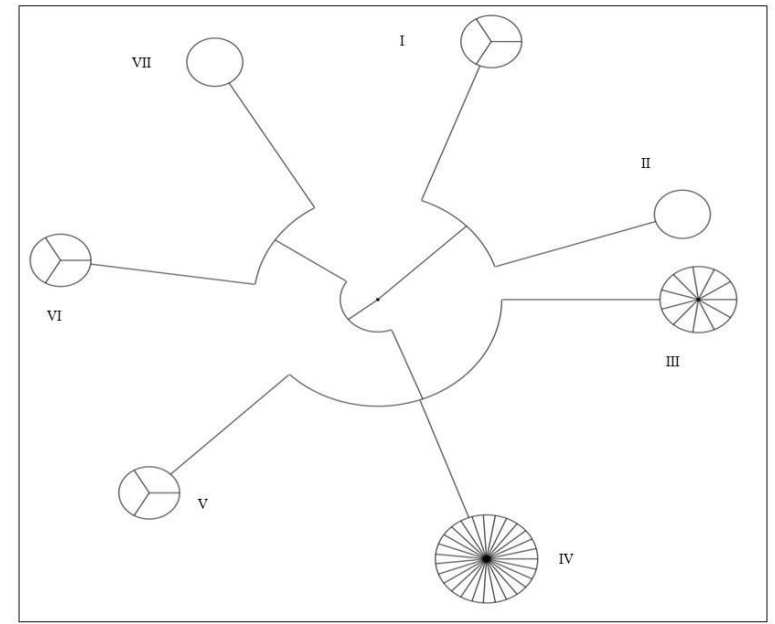

Figure 3. Advanced nodal cluster analysis of minimal inhibitory concentrations of oxytetracycline and chloramphenicol against the motile aeromonad strains. (I) Node of isolates AC2R, 5BFM, 6BFM; (II) Node of isolate NS6; (III): Node of isolates 5BRF, 6BMR, 6CR, GR6, NR2, 5GC, GM6, 6BMM, 6BFW, NW6, FBS6, 5NS; (IV) Node of isolates 4BMR, FBR7, NR7, GR2, NR1, NR8, FBR8, CC2, $5 \mathrm{CC}, \mathrm{CC} 4, \mathrm{CC} 9, \mathrm{FBC} 7, \mathrm{MBC} 7, \mathrm{AC2C}, \mathrm{MBC}$, 3NM, 9BMF, AGMM, GM9, FBM7, MBM7, NM9, MBM8, NW8, CW9, FBS8, CS8; (V) Node of isolates 3BFW, 4CS, 3BFS; (VI) Node of isolates FBC9, CC3, MBM3; (VII) Node of isolate GC4

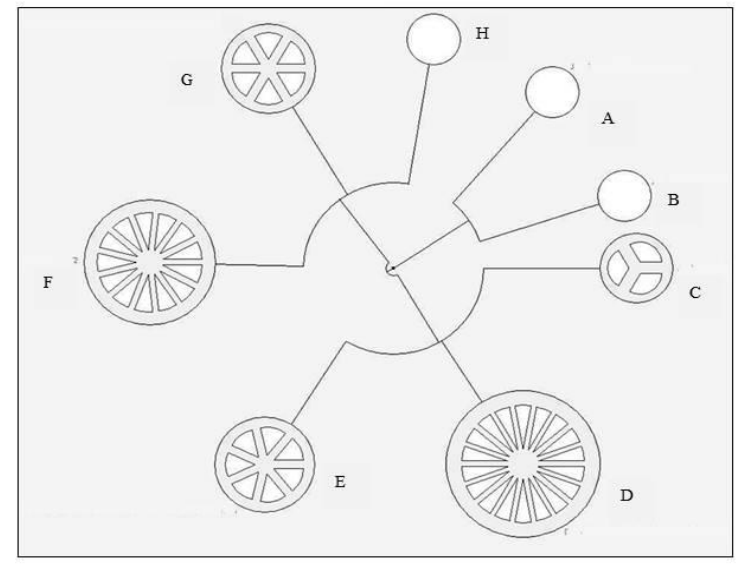

Figure 4. Advanced nodal cluster analysis of minimal inhibitory concentrations of oxytetracycline and chloramphenicol against Escherichia colistrains. (A) Node of isolate JULY-BMR1B; (B) Node of isolate JUNE-NR1; (C) Node of isolates AUG-QNC1, BMR1B, JULY-BMM2A; (D) Node of isolates JULY-BFR2B, SEP-BMR1, NOV-CR1, MAY-QRB1, JULY-BFR1A, SEP-NR1, SEP-BMR1, JUNEBFM2B, SEP-BMM2A, JULY-BFM2, JULY-BMM1B, APRIL-BMC2, JULY-BFC1B，OCT-QBFC2， AUG-ONW2，AUG-QNW1，OCT-CS2, DEC-BFS2'; (E) Node of isolates JUNE-BMR1C, JULY-BMR1B, BFM2, NOV-NM2, JULY-BFW1A, OCT-NW1, JUNE-BFS1A; (F) Node of isolates QBFR2E, QBFR2, JUNE-BMM2H, JUNE-BMFR1B, JUNEBFM2H，JGC2, SJCC2, QBMC1, JCC1, DEC-NC1, JUNE-BFW1B, JUNE-NW2, AUG-QNS2; (G) Node of isolates OCT-BFS2, MAYQBFR2E, MAY-CR1, BFM2H, MAY-OBMM1H, SEP-QBMM1H; $(\mathrm{H})$ Node of isolate AUG-OBMC1 inside the A3 cluster was based on their susceptibility to $\mathrm{CH}$. Although cluster A2 contained the single subgroup of the ${ }^{O T C} C^{R} \mathrm{CH}^{\mathrm{R}}$ strain, it was still associated with both clusters $\mathrm{A} 1$ and A3 on the basis of its resistance to both OTC and $\mathrm{CH}$. Among the $A$. tecta strains tested, only one cluster was formed, which contained the $0 \mathrm{OCC}^{\mathrm{S}} \mathrm{CH}^{\mathrm{s}}$ strains. Among A. caviae strains, cluster A2 correlated with clusters $A 1$ and $A 3$ at similarity levels of $38.9 \%$ and $25.0 \%$, respectively, which were below $40 \%$, again justifying its separation from the other two clusters ${ }^{[24]}$. The subgroups of cluster A1, viz., a11 and a12, were correlated at the $50 \%$ similarity levels, as they showed similar sensitivities only to OTC. The subgroups of cluster A3, viz., a31 and a32, shared 50\% similarity levels to their resistance against OTC. The dendrogrambased cluster analysis of motile aeromonads showed quite high internal homogeneity, as greater than five subgroups, i.e., nine were obtained under the main clusters.

The dendrogram-based cluster analysis of $E$. colistrains from the aquaculture environment painted a different picture. Cluster $A$ contained the subgroups of $0 \mathrm{OTC}^{\mathrm{S}} \mathrm{CH}^{\mathrm{R}}$ strains (al), $\mathrm{OTC}^{\mathrm{S}} \mathrm{CH}^{\mathrm{s}}$ strains (all), and $\mathrm{OTC}^{\mathrm{S}} \mathrm{CH}^{\prime}$ strains (allI), three of which shared 50\% similarity levels. The similarity levels were uniform among the cluster due to three subgroups showing susceptibility to OTC. The similarity levels were again uniform (50\%) among cluster $\mathrm{B}$, which contained the subgroups bl $\left(\mathrm{OTC}^{\mathrm{R}} \mathrm{CH}^{\prime}\right)$, bll $\left(\mathrm{OTC}^{\mathrm{R}} \mathrm{CH}^{\mathrm{S}}\right)$, and bIII (OTC $\left.{ }^{R} \mathrm{CH}^{\mathrm{R}}\right)$, according to their resistance to OTC. Cluster $C$ depicted similar results with subgroups $\mathrm{cl}\left(\mathrm{OTC}^{\prime} \mathrm{CH}^{\prime}\right)$ and cll $\left(\mathrm{OTC}^{\prime} \mathrm{CH}^{\mathrm{s}}\right)$. Clusters A and B shared similarity levels of $23.1 \%$, whereas cluster $C$ shared $20.3 \%$ similarity with clusters $A$ and B. The similarity levels were below $40 \%$, depicting correlations at a lower level, which was evident by the resistance pattern and profile. Dendrogram-based cluster analysis of $E$. coli also showed high internal homogeneity, i.e., 8 clusters. These results suggested efficient clustering for both motile aeromonads and E. coli, in close agreement with Oyelade et al. ${ }^{[25]}$.

On the basis of the nodal clusters generated by BioNumerics, the similarity between the OTC- and CH-resistance/susceptibility profiles of the selected motile aeromonads and E. coli was interpreted. The nodal clusters of III-IV-V nodes, C-D-E nodes, and $\mathrm{F}-\mathrm{G}-\mathrm{H}$ nodes depicted a higher intra-cluster density, in agreement with Emmons et al. ${ }^{[26]}$. Cluster heads VI and VII were interconnected, as their included strains were susceptible to $\mathrm{CH}$. Nodes I and II were interconnected, as both had strains that showed MIC values $>100 \mu \mathrm{g} / \mathrm{ml}$ for $\mathrm{CH}$, i.e., $\mathrm{CH}^{\mathrm{R}}$. Nodes III and V showed susceptibility to OTC. The distance between these two nodes was, however, maximized as their MIC values of OTC were dissimilar. Nodes II and III were placed at a hairbreadth distance as both nodes were comprised of strains that showed MIC values $>100 \mu \mathrm{g} / \mathrm{ml}$ for $\mathrm{CH}$. The advanced nodal cluster analysis of MIC values of $E$. coli resulted in eight nodal clusters. Nodes $F, G$, and $\mathrm{H}$ were interconnected due to their susceptibility to OTC. 
Table 1. Minimum inhibitory concentrations of oxytetracycline and chloramphenicol against motile aeromonads from the aquaculture environment

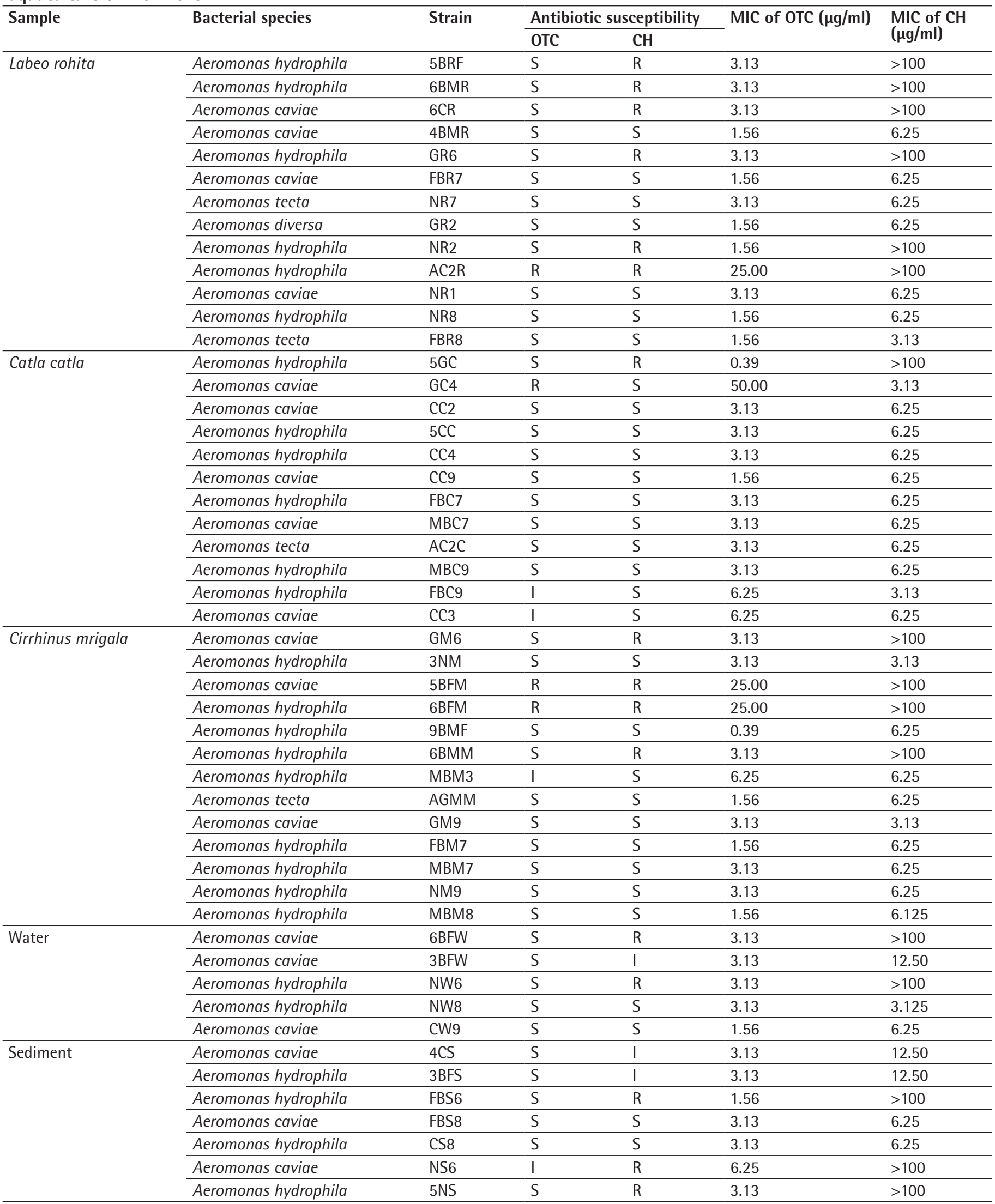


Table 2. Minimum inhibitory concentrations of oxytetracycline and chloramphenicol against Escherichia coli from the aquaculture environment

\begin{tabular}{|c|c|c|c|c|c|}
\hline \multirow[t]{2}{*}{ Sample } & \multirow[t]{2}{*}{ Strain } & \multicolumn{2}{|c|}{ Antibiotic susceptibility } & \multirow[t]{2}{*}{ MIC of OTC $(\mu \mathrm{g} / \mathrm{ml})$} & \multirow[t]{2}{*}{ MIC of $\mathrm{CH}(\mu \mathrm{g} / \mathrm{ml})$} \\
\hline & & OTC & $\mathrm{CH}$ & & \\
\hline \multirow{16}{*}{ Labeo rohita } & BMR1B & $\mathrm{R}$ & $R$ & 50.00 & $>100$ \\
\hline & QBFR2E & $\mathrm{S}$ & $\mathrm{S}$ & 1.56 & 1.56 \\
\hline & QBFR2 & $\mathrm{S}$ & $\mathrm{S}$ & 1.56 & 3.13 \\
\hline & JULY-BMR1B & 1 & 1 & 12.50 & 12.50 \\
\hline & JULY-BFR2B & $\mathrm{R}$ & $\mathrm{S}$ & 50.00 & 3.13 \\
\hline & SEP-BMR1 & $\mathrm{R}$ & $\mathrm{S}$ & 50.00 & 3.13 \\
\hline & MAY-QBFR2E & $\mathrm{S}$ & $\mathrm{R}$ & 3.125 & $>100$ \\
\hline & JUNE-BMR1B & $\mathrm{R}$ & $R$ & 50.00 & 25.00 \\
\hline & NOV-CR1 & $\mathrm{R}$ & $\mathrm{S}$ & 50.00 & 3.13 \\
\hline & MAY-QRB1 & $\mathrm{R}$ & $\mathrm{S}$ & 50.00 & 3.13 \\
\hline & MAY-CR1 & $\mathrm{S}$ & $\mathrm{R}$ & 1.56 & $>100$ \\
\hline & JUNE-NR1 & I & $\mathrm{S}$ & 12.50 & 3.13 \\
\hline & JUNE-BMR1C & $\mathrm{R}$ & I & 25.00 & 12.50 \\
\hline & JULY-BFR1A & $\mathrm{R}$ & $\mathrm{S}$ & 50.00 & 3.13 \\
\hline & SEP-NR1 & $\mathrm{R}$ & $\mathrm{S}$ & 50.00 & 3.13 \\
\hline & SEP-BMR1 & $\mathrm{R}$ & $\mathrm{S}$ & 50.00 & 3.13 \\
\hline \multirow[t]{13}{*}{ Cirrhinus mrigala } & BFM2H & $\mathrm{S}$ & $\mathrm{R}$ & 1.56 & $>100$ \\
\hline & MAY-OBMM1H & $\mathrm{S}$ & $\mathrm{R}$ & 1.56 & $>100$ \\
\hline & BFM2 & $\mathrm{R}$ & I & 50.00 & 12.50 \\
\hline & JUNE-BFM2B & $\mathrm{R}$ & $\mathrm{S}$ & 25.00 & 1.56 \\
\hline & SEP-BMM2A & $\mathrm{R}$ & $\mathrm{S}$ & 25.00 & 3.13 \\
\hline & JULY-BFM2 & $\mathrm{R}$ & $\mathrm{S}$ & 25.00 & 3.13 \\
\hline & SEP-QBMM1H & $\mathrm{S}$ & $\mathrm{R}$ & 1.56 & 50.00 \\
\hline & JULY-BMM2A & $\mathrm{R}$ & $R$ & 50.00 & $>100$ \\
\hline & JUNE-BMM2H & $\mathrm{S}$ & $\mathrm{S}$ & 1.56 & 3.13 \\
\hline & JUNE-BMR1B & $\mathrm{S}$ & $\mathrm{S}$ & 1.56 & 3.13 \\
\hline & JUNE-BFM2H & $\mathrm{S}$ & $\mathrm{S}$ & 1.56 & 3.13 \\
\hline & NOV- NM2 & $\mathrm{R}$ & 1 & 50.00 & 12.50 \\
\hline & JULY-BMM1B & $R$ & $\mathrm{~S}$ & 25.00 & 1.56 \\
\hline \multirow{10}{*}{ Catla catla } & $\mathrm{JGC2}$ & $\mathrm{S}$ & $\mathrm{S}$ & 1.56 & 1.56 \\
\hline & SJCC2 & $\mathrm{S}$ & $\mathrm{S}$ & 1.56 & 1.56 \\
\hline & QBMC1 & $\mathrm{S}$ & $\mathrm{S}$ & 1.56 & 1.56 \\
\hline & $\mathrm{JCC} 1$ & $\mathrm{~S}$ & $\mathrm{~S}$ & 1.56 & 1.56 \\
\hline & APRIL-BMC2 & $\mathrm{R}$ & $\mathrm{S}$ & 50.00 & 1.56 \\
\hline & JULY-BFC1B & $\mathrm{R}$ & $\mathrm{S}$ & 25.00 & 1.56 \\
\hline & DEC-NC1 & $\mathrm{S}$ & $\mathrm{S}$ & 1.56 & 1.56 \\
\hline & AUG-OBMC1 & $\mathrm{S}$ & 1 & 1.56 & 12.50 \\
\hline & AUG-QNC1 & $\mathrm{R}$ & $R$ & 50.00 & $>100$ \\
\hline & OCT-QBFC2 & $\mathrm{R}$ & $\mathrm{S}$ & 50.00 & 3.13 \\
\hline \multirow[t]{6}{*}{ Pond water } & AUG-ONW2 & $R$ & $\mathrm{~S}$ & 25.00 & 3.13 \\
\hline & JULY-BFW1A & $\mathrm{R}$ & 1 & 25.00 & 12.50 \\
\hline & JUNE-BFW1B & $\mathrm{S}$ & $\mathrm{S}$ & 1.56 & 3.13 \\
\hline & JUNE-NW2 & $\mathrm{S}$ & $\mathrm{S}$ & 1.56 & 3.13 \\
\hline & AUG-ONW1 & $\mathrm{R}$ & $\mathrm{S}$ & 25.00 & 1.56 \\
\hline & OCT-NW1 & $\mathrm{R}$ & 1 & 25.00 & 12.50 \\
\hline \multirow[t]{5}{*}{ Pond sediment } & AUG-QNS2 & $\mathrm{S}$ & $S$ & 1.56 & 3.125 \\
\hline & OCT-CS2 & $\mathrm{R}$ & $\mathrm{S}$ & 50.00 & 1.56 \\
\hline & OCT-BFS2 & $\mathrm{S}$ & $\mathrm{R}$ & 1.56 & 50.00 \\
\hline & DEC-BFS2 & $\mathrm{R}$ & $\mathrm{S}$ & 25.00 & 1.56 \\
\hline & JUNE-BFS1A & $R$ & 1 & 50.00 & 12.50 \\
\hline
\end{tabular}


Clusters $A$ and $B$ contained single strains and were interconnected, as both showed resistance (I) to OTC with an MIC value of 12.5 $\mu \mathrm{g} / \mathrm{ml}$. The strains in cluster heads $\mathrm{C}, \mathrm{D}$ and $\mathrm{E}$ showed MIC values of OTC in the range of $25-50 \mu \mathrm{g} / \mathrm{ml}$. The shortest distance between nodal clusters was observed between $B$ and $C$ due to their similarity in MIC values of OTC $(50 \mu \mathrm{g} / \mathrm{ml})$, inferring that a shorter distance meant a higher similarity. The farthest distance among the pairs of nodal clusters/heads was observed in C-E nodes, possibly due to the wide variance of MIC values of $\mathrm{CH}$ among these strains. Further, no overlapping clusters were displayed, as evidenced by the low similarity levels ${ }^{[27]}$. It also signified the strong presence of separate attributes (antibiotic susceptibility) for separate clusters. These observations on the varied susceptibility among motile aeromonads and $E$. coli from the aquaculture environment in peri-urban Kolkata with no history of antibiotic usage implied the possible contamination of carps with ARB from domestic and hospital effluents. Such contamination of ARB from various other sectors may decrease the effectiveness of antibiotic therapy in carp aquaculture.

The present study selected a vast number of phenotypically characterized Aeromonas and E. coli strains $(n=100)$ for cluster analysis on the basis of the observed MIC values, which subjects this research to a limitation. The authors recommend that future researchers perform cluster analysis for virulent or pathogenic strains that have been characterized by molecular techniques.

\section{Conclusion}

In general, the results of the present study revealed that cultured and retail market carps were contaminated with antibioticresistant motile aeromonads and $E$. coli. The clustering of strains by BioNumerics provided a brief input at the similarity and correlativity among the strains of motile Aeromonas and E. coli from the aquaculture environments of the EKW and peri-urban Kolkata. Although a greater number of clusters were obtained from the dendrogram-based cluster analysis and advanced nodal cluster analysis of motile aeromonads as a group, E. coli strains from aquaculture environments exhibited high heterogeneity in antibiotic susceptibility, which is a cause for serious concern. This BioNumerics-based clustering would provide an efficient scope for future research on ARB from aquaculture systems and their management.

\section{Acknowledgements}

The authors thank the Vice-Chancellor, West Bengal University of Animal and Fishery Sciences, Kolkata for providing necessary facilities to carry out the work.

\section{Ethics}

Ethics Committee Approval: Experimental protocols were approved by the Indian Council of Agricultural Research,
Government of India, New Delhi under the All-India Network Project on Fish Health (No. CIBA/AINP-FH/2015-16 dated 02.06.2015) and fulfilled the ethical guidelines, including adherence to the legal requirements of India. The conventional regulatory framework may not be applied regarding use of experimental animals in agricultural production research as per the guidelines of the "Committee for the Purpose of Control and Supervision of Experiments on Animals", Government of India and, hence, Ethical Committee approval was not needed.

Pee-review: Externally and internally peer-reviewed.

\section{Authorship Contributions}

Concept and Design: A.B., Q.A.Q., T.J.A., Data Collection or Processing: A.B., Q.A.Q., Analysis or Interpretation: A.B., T.J.A., Literature Search: A.B., Q.A.Q., Writing: A.B., T.J.A.

Conflict of Interest: No conflict of interest was declared by the authors.

Financial Disclosure: The work was supported by the Indian Council of Agricultural Research, Government of India, New Delhi under the All India Network Project on Fish Health (Grant F. No. CIBA/AINP-FH/2015-16 dated 02.06.2015).

\section{References}

1. Romero J, Feijoó CG, Navarrete P. Antibiotics in aquaculture - Use, abuse and alternatives. in: Carvalho E, David GS, Silva RJ (Eds.). Health and Environment in Aquaculture. InTech, 2012:159-199. Available at: https:// www.intechopen.com/books/health-and-environment-in-aquaculture/

2. World Health Organization (WHO). Antibiotic Resistance, Geneva, Switzerland. Last accessed date: 2019. Available from: https://www.who. int/news-room/fact-sheets/detail/antibiotic-resistance

3. Janda JM, Abbott SL. The genus Aeromonas: taxonomy, pathogenicity, and infection. Clin Microbiol Rev. 2010; 23:35-73.

4. Austin B, Austin DA. Bacterial fish pathogens: Disease of farmed and wild fish. 5th edn. Chichester: Praxis Publication Ltd, 2012.

5. The International Commission on Microbiological Specifications for Foods. Microorganisms in foods (ICMSF). In: Sampling for Microbiological Analysis: Principles and Scientific Applications. 2nd ed. Toronto Press, 1986. Available from: https://www.tandfonline.com/doi/abs/10.1080/00401706.1977.10489 539

6. Niemi M, Taipalinen I. Faecal indicator bacteria at fish farms. Hydrobiologia. 1982;86:171-5.

7. Oliveira RV, Oliveira MC, Pelli A. Disease infection by Enterobacteriaceae family in Fishes: A review. J Microbiol Exp. 2017;4:e00128.

8. Nadimpalli M, Vuthy $Y$, de Lauzanne A, Fabre L, Criscuolo A, Gouali M, Huynh BT, Naas T, Phe T, Borand L, Jacobs J, Kerléguer A, Piola P, Guillemot $D$, Le Hello $S$, Delarocque-Astagneau E; BIRDY study group. Meat and Fish as Sources of Extended-Spectrum $\beta$-Lactamase-Producing Escherichia coli, Cambodia. Emerg Infect Dis. 2019;25:126-31.

9. Department of Animal Husbandry Dairying and Fisheries (DAHDF) Handbook of fisheries statistics: 2017-18. Government of India, New Delhi, 2018.

10. Lin $M$, Wu $X, Y a n$ Q, Ma $Y$, Huang $L$, Qin $Y, X u X$. Incidence of antimicrobialresistance genes and in tegrons in antibiotic-resistant bacteria isolated from eels and aquaculture ponds. Dis Aquat Org. 2016;120:115-23. 
11. Chuah LO, Effarizah ME, Goni AM, Rusul G. Antibiotic application and emergence of multiple antibiotic resistance (MAR) in global catfish aquaculture. Curr Environ Health Rep. 2016;3:118-27.

12. Abraham TJ, Bardhan A. Emergence and spread of antimicrobial resistance in motile aeromonads of the aquaculture environment. Indian J Anim Health. 2019;58:39-52.

13. Rahiman MKM, Hatha MAA, Selvam GAD, Thomas AP. Relative prevalence of antibiotic resistance among heterotrophic bacteria from natural and culture environments of freshwater prawn, Macrobrachium rosenbergii. J World Aquacult Soc. 2016;47:470-80.

14. Ye L, Zhang L, Li X, Shi L, Huang Y, Wang HH. Antibiotic-resistant bacteria associated with retail aquaculture products from Guangzhou, China. J Food Prot. 2013;76:295-301.

15. Kumar S, Lekshmi M, Parvathi A, Nayak BB, Varela MF. Antibiotic resistance in seafood-borne pathogens. In: Singh OV (ed) Food-borne pathogens and antibiotic resistance, Wiley-Blackwell, USA, 2017:397-416.

16. Mainda G, Bessell PR, Muma JB, McAteer SP, Chase-Topping ME, Gibbons J, Stevens MP, Gally DL, deC Bronsvoort BM. Prevalence and patterns of antimicrobial resistance among Escherichia coli isolated from Zambian dairy cattle across different production systems. Sci Rep. 2015;5:12439.

17. Naceur B, Boudjemâa BM. Antibiotic resistance of enterococci isolated from raw camel milk in the South West of Algeria. Afr J Microbiol Res. 2016;10:420-7.

18. Guzzi PH, Masciari E, Mazzeo GM, Zaniolo C. A discussion on the biological relevance of clustering results. In: Bursa M, Khuri S, Renda ME (eds) Information Technology in Bio- and Medical Informatics. ITBAM 2014. Lecture Notes in Computer Science. Springer. 2014:30-44.
19. United States Food and Drug Administration. Approved Aquaculture Drugs (USFDA). Last accessed date: 2019 Apr 12. Available from: https://www.fda. gov/animal-veterinary/aquaculture/approved-aquaculture-drugs

20. Abraham TJ. Food safety hazards related to emerging antibiotic-resistant bacteria in cultured freshwater fish of Kolkata, India. Adv J Food Sci Technol. 2011;3:69-72.

21. Collins $\mathrm{CH}$, Lynes PM, Grange JM, Falkinham III JO. Collins and Lyne's Microbiological methods. 8th edn. London: Arnold Publishers, 2004.

22. Clinical and Laboratory Standards Institute (CLSI). Performance standards for antimicrobial disk susceptibility tests. Approved Standard, 7th ed. Document M02-A11. CLSI Pennsylvania, USA, 2012.

23. Clinical and Laboratory Standards Institute (CLSI). Methods for antimicrobial susceptibility testing for human mycoplasmas; Approved Guideline. Document M43-A. CLSI, Pennsylvania, USA, 2011.

24. Chai LC, Fatimah AB, Ghazali FM, Lee HY, Tunung R, Shamsinar AT, Laila RAS, Thahirahtul AZ, Malakar PM, Nakaguchi Y, Nishibuchi M, Son R. Biosafety of Campylobacter jejuni from raw vegetables consumed as Ulam with reference to their resistance to antibiotics. Int Food Res J. 2008;15:125-34.

25. Oyelade J, Isewon I, Oladipupo F, Aromolaran O, Uwoghiren E, Ameh F, Achas $M$, Adebiyi E. Clustering algorithms: their application to gene expression data. Bioinform Biol Insights. 2016;10:237-53.

26. Emmons $S$, Kobourov $S$, Gallant $M$, Börner K. Analysis of Network Clustering Algorithms and Cluster Quality Metrics at Scale. PLoS One. 2016;11:e0159161.

27. Bolin JH, Edwards JM, Finch WH, Cassady JC. Applications of cluster analysis to the creation of perfectionism profiles: a comparison of two clustering approaches. Front Psychol. 2014;5:343. 